\title{
OPTIMASI PENGUNAAN SUMBER ENERGI LISTTRIK DI DEPARTEMEN TEKNIK ELEKTRO UNIVERSITAS DIPONEGORO DENGAN MENGGUNAKAN PERANGKAT LUNAK HOMER
}

\author{
Andre Barry Prawira*), Bambang Winardi dan Agung Nugroho \\ Departemen Teknik Elektro, Universitas Diponegoro \\ Jl. Prof. Sudharto, SH, Kampus UNDIP Tembalang, Semarang 50275, Indonesia \\ ${ }^{*}$ E-mail: andrebarry22@gmail.com
}

\begin{abstract}
Abstrak
Departemen Teknik Elektro Universitas Diponegoro terletak di Semarang,Jawa Tengah. Lokasi ini memiliki iradiasi yang cukup besar,hal ini dapat dimanfaatkan untuk membangun pembangkit listrik tenaga surya (PLTS). PLTS adalah sistem pembangkit yang memanfaatkan sinar matahari yang nantinya akan dikonversikan menjadi energi listrik menggunakan PV. HOMER adalah suatu model sistem pembangkit skala kecil untuk mempermudah dalam mengevaluasi desain dari jaringan tunggal (off-grid) maupun jaringan yang terkoneksi dengan sistem ( grid-connected ). HOMER memungkinkan pemodelan untuk membandingkan banyak opsi desain yang berbeda bedasarkan manfaat teknis dan ekonomi mereka. Dengan menggunakan HOMER diharapakan dapat mengetahui konfigurasi sistem pembangkit yang optimal juga dapat mengetahui besar potensi energi terbaharukan di Teknik Elektro. Hasilnya dengan menggunakan HOMER di dapat konfigurasi yang optimal yaitu photovoltaic (PV)-Grid,dengan $255.530 \mathrm{kWh} /$ tahun untuk daya yang dihasilkan oleh PV dan $158.788 \mathrm{kWh} /$ tahun daya yang disuplai oleh grid untuk memenuhi permintaan beban sebesar $414.319 \mathrm{kWh} / \mathrm{tahun}$.
\end{abstract}

Kata kunci : energi terbaharukan, PLTS, HOMER, grid, photovoltaic

\begin{abstract}
The department of electrical engineering university diponegoro located in semarang, central java.This location having irradiated large enough, this can be used to build solar power generating stations ( plts ).Plts is a system power station who use of sunlight that will be being converted into electrical energy use pv. To homer was some kind of model a system of the operation of its a small scale to make it easy for in is the need of evaluation a design of a worldwide network of only begotten or unique son ( off-grid ) as well as the tissue on which it is connected with a system of ( grid-connected ) . Homer made it possible for modeling in order to compare many an option a different design bedasarkan of the benefits of the technical skills nor the their economic.By the use of homer competition is expected can understand my insight into the operation of its the system configuration of optimal able to find out also large potential energy of renewable in electrical engineering. The results using homer in be optimum configuration of photovoltaic (PV) -grid,with 255.530 / program for power that year produced by pv 158.788 / years and given resources supplied by the grid to meet a demand 414.319 / program of the year.
\end{abstract}

Keywords: renewable energy, plts, homer, the grid, photovoltaic,

\section{Pendahuluan}

Universitas Diponegoro adalah salah satu kampus negeri yang terletak di Kecamatan Tembalang,Kota Semarang ,Provinsi Jawa Tengah . Secara Geografis ,Universitas Diponegoro terletak pada posisi $7^{\circ} 03^{\prime} 04.5^{\prime \prime}$ Lintang Selatan dan $110^{\circ} 26^{\prime} 27.5$ Bintang Timur. Universitas Diponegoro terdiri dari 11 Fakultas dan 2 sekolah,dengan rincian 21 Program Studi Diploma (D3),51 Program Studi Sarjana, 35 Program Studi Magister (S2), 18 Program Pendidikan Dokter Spesialis, 3 Program Profesi dan 13 Program Studi Doktor (S3). Salah satu Program Sarjana yang ada di Universitas Diponegoro adalah S1 Teknik
Elektro yang merupakan salah satu Jurusan di Fakultas Teknik.[1]

Bedasarkan data Badan Meteorologi Klimatologi dan Geofisika Stasiun Klimatologi Semarang, Daerah Kota Semarang yang merupakan wilayah Teknik Elektro Universitas Diponegoro berada ,memiliki rata-rata radiasi matahari sebesar $7,96 \mathrm{kWh} / \mathrm{m}^{2} / \mathrm{d}$, dan juga memiliki ratarata suhu sebesar $28,1^{\circ} \mathrm{C}[2]$. Dimana hal ini data ini dapat dimanfaatkan dengan optimal untuk menghasilkan energi listrik yang dapat membantu menghemat biaya konsumsi listrik di Teknik Elektro Universitas Diponegoro. 
Pembangkit listrik tenaga surya adalah pembangkit listrik yang mengubah energi surya menjadi energi listrik. Pembangkitan listrik bisa dilakukan dengan dua cara, yaitu secara langsung menggunakan fotovoltaik dan secara tidak langsung dengan pemusatan energi surya. Fotovoltaik mengubah secara langsung energi cahaya menjadi listrik menggunakan efek fotoelektrik. Pemusatan energi surya menggunakan sistem lensa atau cermin dikombinasikan dengan sistem pelacak untuk memfokuskan energi matahari ke satu titik untuk menggerakan mesin kalor...

HOMER adalah suatu model sistem pembangkit skala kecil (micropower) untuk mempermudah dalam mengevaluasi desain dari jaringan tunggal (off-grid) maupun jaringan yang terkoneksi dengan sistem ( gridconnected ). HOMER memungkinkan pemodelan untuk membandingkan banyak opsi desain yang berbeda bedasarkan manfaat teknis dan ekonomi mereka. Perangkat lunak ini melakukan perhitungan keseimbangan energi untuk setiap 8.760 jam dalam setahun. Kemudian menentukan konfihurasi yang layak apakah dapat memenuhi kebutuhan listrik dibawah kondisi yang ditentukan,perkiraan biaya instalasi dan sistem operasi selama masa proyek.[3]

Studi sejenis yang pernah dilakukan adalah, Taufik Chemistryadha Wijaya melakukan studi kelayakan sistem tenaga hibrida di Desa Margajaya Bengkulu Utara dengan mengoptimalkan tenaga biomassa,surya,mikrohidro dan baterai[4]. Dan penelitian Lambertus Sinaga yang melakukan studi kelayakan sistem tenaga hibrida di Pulau Nyamuk KarimunJawa Jawa Tengah dengan mengoptimalkan tenaga biomassa,surya,angin dan diesel generator sebagai tenaga cadangan.[5]

Tujuan pembuatan penelitian ini adalah sebagai berikut :

1. Mengetahui besar potensi energi matahari yang terdapat di Teknik Elektro Universitas Diponegoro.

2. Mengetahui beban harian ,beban puncak, beban ratarata, dan faktor beban.

3. Mengetahui modal awal untuk membangun PLTS

4. Mengetahui pembelian dan penjualan energi listrik menggunakan sistem hibrida.

5. Menganalisis kinerja masing-masing komponen sistem pembangkit listrik saat bekerja bersama-sama dengan menggunakan perangkat lunak HOMER untuk kondisi on-grid.

6. Menentukan konfigurasi sistem pembangkit listrik hibrida yang optimal, dilihat dari biaya produksi energi listrik atau NPC (Net Present Cost) dan ketersediaan sumber energi terbarukan di Teknik Elektro Undip menggunakan perangkat lunak HOMER untuk kondisi on-grid.

\section{Metode \\ 2.1. Perancangan Simulasi PLTS di Departemen Teknik Elektro}

Diagram alir perancangan simulasi PLTS di Departemen Teknik Elektro Universitas Diponegoro ,Kecamatan Tembalang,Kota Semarang, Provinsi Jawa Tengah adalah sebagai berikut :

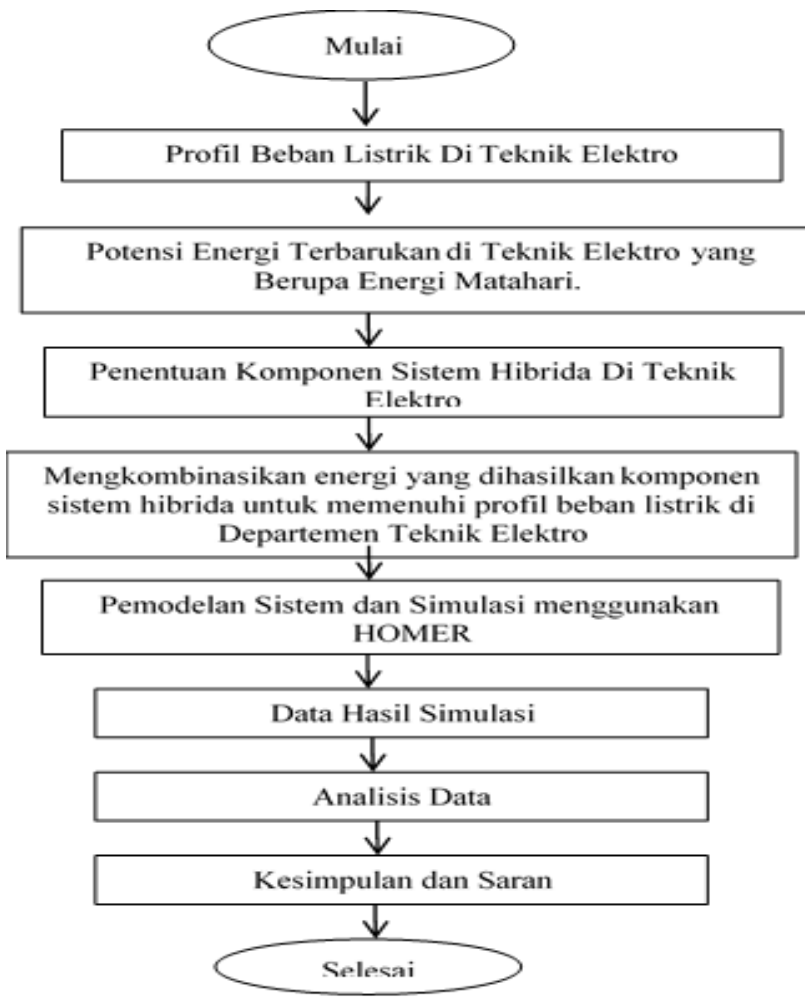

Gambar 1. Diagram alir metode perancangan[10]

\subsection{Data Sistem}

Data sistem perancangan simulasi PLTS ini terdiri dari beberapa bagian penting, yaitu alat elektronik yang terpasang di Teknik Elektro, profil beban listrik di Teknik Elektro, dan potensi energi terbarukan di Teknik Elektro.

\subsubsection{Profil Beban}

Penelitian ini menggunakan data beban dari Departemen Teknik Elektro Undip, Kecamatan Tembalang, Kota Semarang. Selama ini Teknik Elektro hanya dialari listrik oleh PLN saja. 
Tabel 1. Alat Elektronik di Teknik Elektro

\begin{tabular}{|c|c|c|}
\hline Alat Elektronik & Jumlah & Watt/Unit \\
\hline Lampu TL & 13 & $36 \mathrm{w}$ \\
\hline Lampu TL & 142 & $18 w$ \\
\hline AC Panasonic CS PN18RKP 2KP & 5 & $1940 \mathrm{w}$ \\
\hline AC National & 8 & $1500 w$ \\
\hline Komputer Lenovo Putih & 35 & $120 w$ \\
\hline Lampu SL & 158 & $23 w$ \\
\hline Lampu LED & 59 & $10.5 w$ \\
\hline AC Daikin & 2 & $1500 w$ \\
\hline AC Panasonic CS PC18NKP 2PK & 16 & $1920 \mathrm{w}$ \\
\hline Komputer Lenovo Hitam & 26 & $220 w$ \\
\hline Dispenser Miyako & 1 & $420 w$ \\
\hline Monitor Samsung PS 42E7s & 1 & 310 \\
\hline AC Panasonic CS PN18SKP 2PK & 15 & $1660 w$ \\
\hline Kipas Maspion & 9 & $45 w$ \\
\hline Kulkas Polytron SCP 15 series & 2 & $160 w$ \\
\hline LCD Epson EB X36 & 2 & $277 w$ \\
\hline Amplifier TOA ZA 1025 & 10 & $25 w$ \\
\hline CCTV & 7 & $12 w$ \\
\hline LCD SONY VPL EW255 & 3 & $314 w$ \\
\hline LCD Epson EB 1955 & 3 & $337 w$ \\
\hline LCD Acer XD1150 & 3 & $243 w$ \\
\hline Pompa Air GrundFos JD Basic 5 & 3 & $1500 w$ \\
\hline Kipas Cosmos & 1 & $46 w$ \\
\hline Kipas Maspion F 167 S & 1 & $55 w$ \\
\hline Lampu Sorot Goll CEIP65 & 4 & $550 w$ \\
\hline Dispenser Royal RCA 2111 IX & 2 & $500 \mathrm{w}$ \\
\hline Canon IR 3300 & 2 & $1350 w$ \\
\hline Kulkas Polytron SCP 15 series & 1 & $160 w$ \\
\hline
\end{tabular}

Tabel 2. Profil Beban Weekdays

\begin{tabular}{cc}
\hline Jam & Beban (kWh) \\
\hline $00.00-01.00$ & 0.37 \\
\hline $01.00-02.00$ & 0.37 \\
\hline $02.00-03.00$ & 0.37 \\
\hline $03.00-04.00$ & 0.37 \\
\hline $05.00-05.00$ & 0.37 \\
\hline $06.00-07.00$ & 0.37 \\
\hline $07.00-08.00$ & 6.33 \\
\hline $08.00-09.00$ & 66.93 \\
\hline $09.00-10.00$ & 125.967 \\
\hline $10.00-11.00$ & 125.967 \\
\hline $11.00-12.00$ & 125.967 \\
\hline $12.00-13.00$ & 125.967 \\
\hline $13.00-14.00$ & 120.287 \\
\hline $14.00-15.00$ & 125.967 \\
\hline $15.00-16.00$ & 125.967 \\
\hline $16.00-17.00$ & 127.532 \\
\hline $17.00-18.00$ & 127.532 \\
\hline $18.00-19.00$ & 62.434 \\
\hline $19.00-20.00$ & 0.37 \\
\hline $20.00-21.00$ & 0.37 \\
\hline $21.00-22.00$ & 0.37 \\
\hline $22.00-23.00$ & 0.37 \\
\hline $23.00-00.00$ & 0.37 \\
\hline & 0.37 \\
\hline
\end{tabular}

Tabel 3. Profil Data Weekend

\begin{tabular}{|c|c|}
\hline Jam & Beban (kWh) \\
\hline $00.00-01.00$ & 0.37 \\
\hline $01.00-02.00$ & 0.37 \\
\hline $02.00-03.00$ & 0.37 \\
\hline $03.00-04.00$ & 0.37 \\
\hline $04.00-05.00$ & 0.37 \\
\hline $05.00-06.00$ & 0.37 \\
\hline $06.00-07.00$ & 6.33 \\
\hline $07.00-08.00$ & 1.927 \\
\hline $08.00-09.00$ & 2.017 \\
\hline $09.00-10.00$ & 2.017 \\
\hline $10.00-11.00$ & 2.017 \\
\hline $11.00-12.00$ & 2.017 \\
\hline $12.00-13.00$ & 2.017 \\
\hline $13.00-14.00$ & 2.017 \\
\hline $14.00-15.00$ & 2.017 \\
\hline $15.00-16.00$ & 2.017 \\
\hline $16.00-17.00$ & 6.517 \\
\hline $17.00-18.00$ & 1.927 \\
\hline $18.00-19.00$ & 0.37 \\
\hline $19.00-20.00$ & 0.37 \\
\hline $20.00-21.00$ & 0.37 \\
\hline $21.00-22.00$ & 0.37 \\
\hline $22.00-23.00$ & 0.37 \\
\hline $23.00-00.00$ & 0.37 \\
\hline
\end{tabular}

\subsubsection{Potensi Energi Matahari}

Potensi energi Matahari sebagai sumber energi dinyatakan dalam data indeks kecerahan (Clearnex Incex) dan radiasi sinar matahari (Solar Radiation) yaitu rata-rata global radiasi matahari pada permukaan horizontal, dinyatakan dalam $\mathrm{kWh} / \mathrm{m}^{2}$, untuk setiap hari dalam satu tahun [6]. Data surface meteorology and solar energy (SMSE) dari Badan Meteorologi, klimatologi, dan Geofisika (BMKG) telah digunakan sebagai sumber informasi radiasi Matahari di Teknik Elektro. Berikut ini adalah grafik potensi energi Matahari Teknik Elektro.

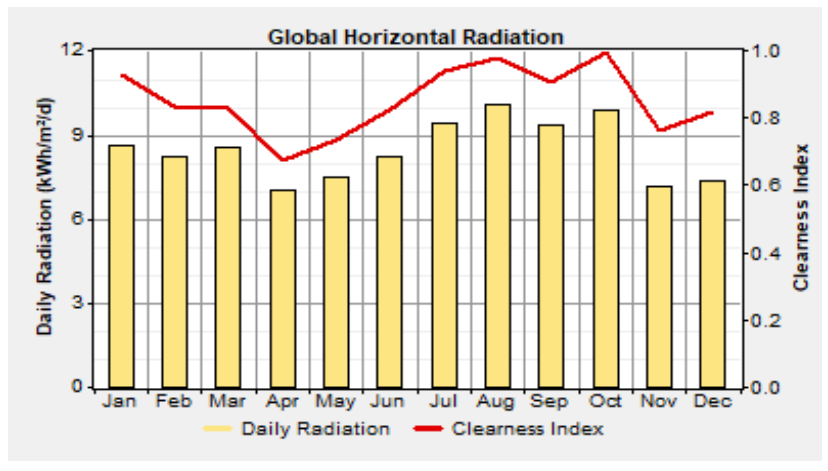

Gambar 2. Potensi energi Matahari di Teknik Elektro 


\subsubsection{Komponen Utama Sistem Pembangkit Listrik Tenaga Hibrida}

Semua harga investasi yang digunakan pada simulasi ini didapat di Teknik Elektro yang telah dikonversikan ke dalam mata uang US\$ dengan nilai kurs transaksi Bank Indonesia, yaitu kurs jual US\$1 sebesar Rp 14.515 .

\section{A. Panel Surya (PV)}

HOMER memodelkan PV array sebagai peralatan yang memproduksi energi DC. Daya Ppv (DC) yang dibangkitkan oleh modul surya dengan mengabaikan efek temperatur pada PV.

Biaya dari PV array ditentukan melalui biaya modal yang dimiliki (\$), biaya pengganti komponen (\$), dan biaya operasi \& pemeliharaan (\$/yr). Biaya pengganti adalah biaya untuk mengganti sel surya apabila mengalami kerusakan hingga batas waktu garansi.

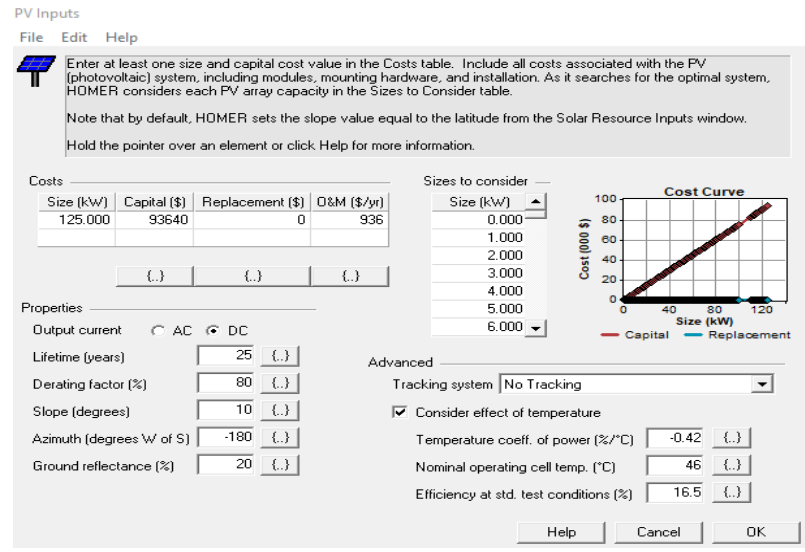

Gambar 3. Parameter masukan panel surya[11]

\section{B. Generator Diesel}

HOMER dapat memodelkan sistem tenaga listrik sebanyak tiga generator, dengan keluaran berupa AC/DC, dan bahan bakar yang berbeda. Kurva bahan bakar menggambarkan jumlah bahan bakar yang dikonsumsi oleh generator untuk menghasilkan listrik.

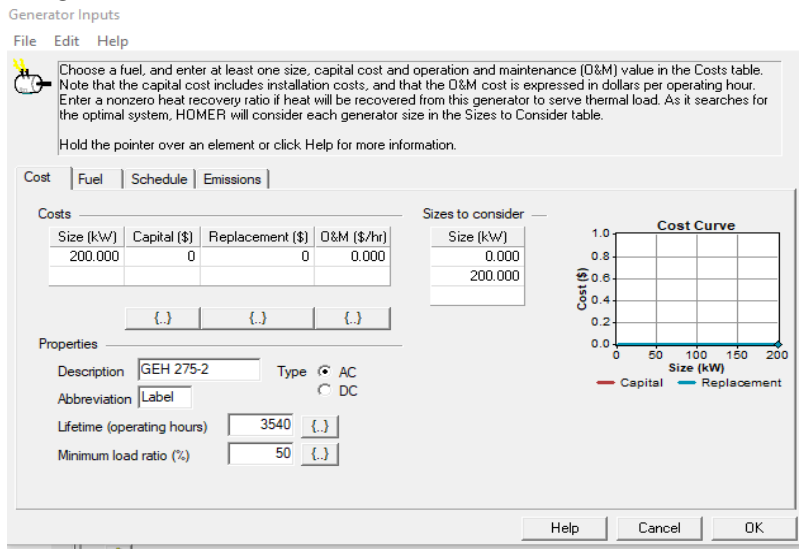

Gambar 4. Parameter masukan generator diesel

\section{Konverter}

Konverter yang digunakan adalah jenis Grid Tie Inverter yang digunakan dalam sistem PLTS OnGrid tipe GTIB100-G1.2 dai Princeton Power System . Pemilihan inverter jenis ini dengan pertimbangan karena spesifikasi dari inverter ini dapat terhubung dengan jaringan listrik PLN, sehingga dapat menentukan kapan harus mengambil listrik dari PLN dan kapan memasok listrik hasil PLTS ke jaringan PLN.

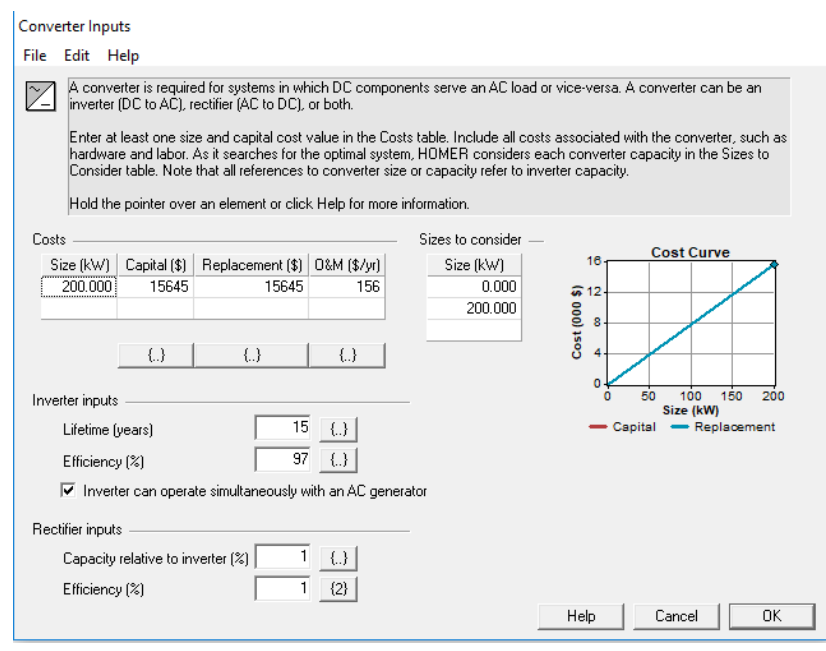

\section{Gambar 5. Parameter masukan inverter[12]}

\section{Grid}

Perencanaan sistem pembangkit hibrida kali ini di buat dengan sistem on-grid sehingga membutuhkan aliran listrik dari PLN. Di HOMER sendiri parameter yang dimasukkan adalah harga pembelian dan juga harga penjualan listrik tersebut.

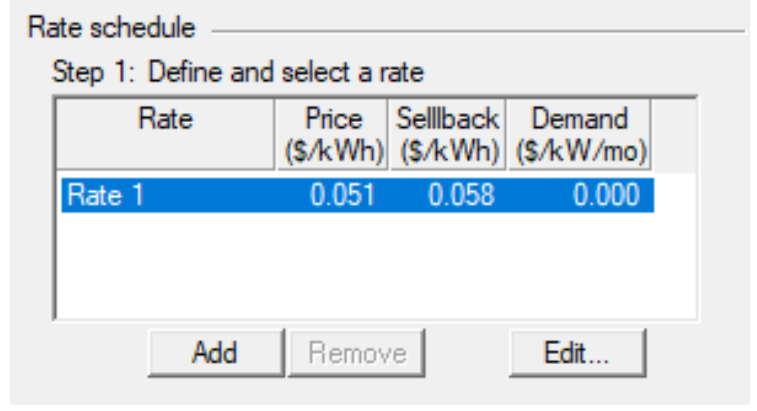

Gambar 6. Parameter masukan Grid

\section{Hasil dan Analisis \\ 3.1. Hasil Optimasi HOMER}

Proses optimasi dilakukan setelah proses simulasi selesai dilakukan. Proses simulasi awal ini bertujuan untuk menentukan variabel ukuran optimum pada masing- 
masing komponen utama yang terpasang saat beroperasi sendiri.

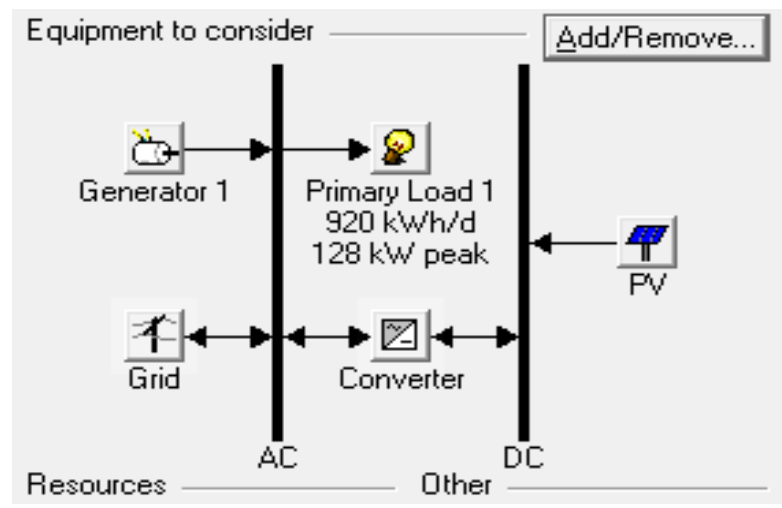

Gambar 7. Konfigurasi sistem pembangkit hibrida saat optimasi

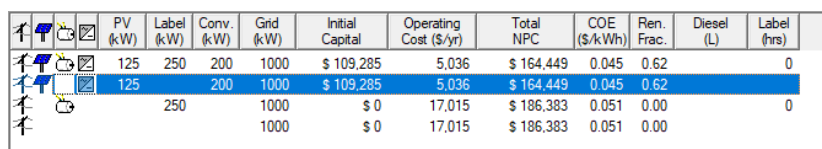

Gambar 8. Konfigurasi optimum sistem PLTH hasil optimasi HOMER

HOMER mengurutkan hasil konfigurasi berdasarkan nilai NPC (Net Presenet Cost) terkecil karena NPC merupakan biaya keseluruhan sistem selama jangka waktu tertentu. Hasil konfigurasi sistem PLTH yang optinum ditunjukan pada Gambar 8.

Konfigurasi pembangkit listrik hibrida yang optimum yaitu terdiri dari panel surya (photovoltaic) $125 \mathrm{~kW}$,konverter $200 \mathrm{~kW}$, dan grid. Denan nilai NPC paling rendah yang $\$ 164.449$.

\subsection{Produksi Listrik Saat Bersistem Hibrida}

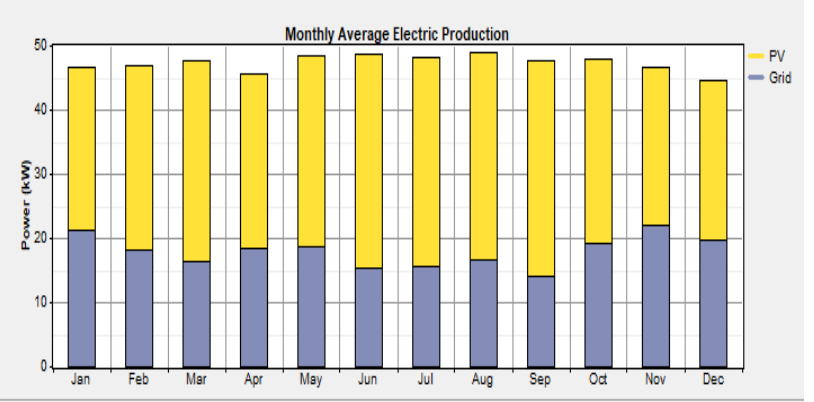

Gambar 9. Rata-rata produksi energi listrik pada sistem

Gambar 9 di atas menunjukkan rata-rata produksi energi listrik masing-masing komponen. Parameter keluaran yang terdapat pada grafik di atas adalah sel surya (kuning), dan
Grid (Ungu). Total produksi listrik yang dihasilkan oleh sistem panel surya dan grid rata-rata pertahun sebesar $414.319 \mathrm{kWh}$.

Excess electricity atau kelebihan listrik yang terdapat pada sistem ini adalah sebesar $0.000989 \mathrm{kWh}$ pertahun atau 0.00 $\%$. Kelebihan listrik ini adalah selisih total produksi energi listrik selama satu tahun yang dihasilkan oleh sistem dan total beban yang disuplai. Renewable Fraction pada sistem sebesar $0.617 \%$. Renewable Fraction adalah persentase jumlah energi terbaharukan pada sistem.

\subsubsection{Daya Yang Dihasilkan PLTS}

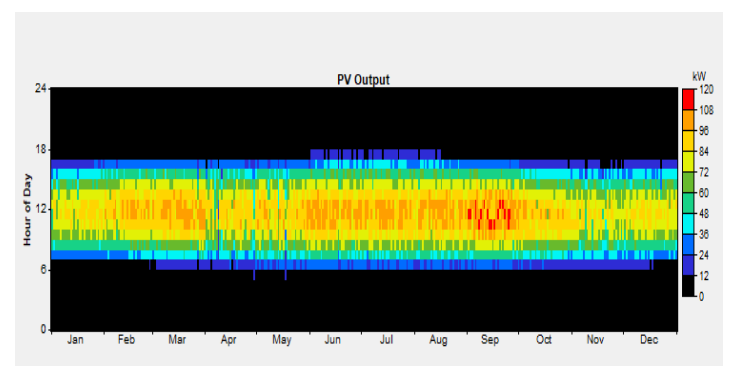

Gambar 10. Daya yang dihasilkan PLTS

Gambar 10 merupakan daya yang dihasilkan oleh PLTS yang terjadi selama setahun yang terjadi dalam rentang waktu 24 jam dengan hasil simulasi yang menunjukkan bahwa daya output akan maksimal pada pukul 10.00-15.00 dengan total produksi energi pertahun sebesar 255.530 kWh.

\subsubsection{Daya Yang Dihasilkan Grid}

Tabel 4 adalah hasil simulasi dari HOMER yang menunjukkan angka Energi yang di beli (Energy Purchased), Energi yang terjual (Energy Sold) , Net Purchases, Peak Demand,Energy Charge dan Demand Charge.

Dapat dilihat di kolom energi terjual dan energi yang dibeli, di setiap bulannya terjadi perbedaan angka, hal ini bisa saja terjadi karna pengaruh beban tiap bulannya dan iradiasi matahari tiap bulannya sehingga mempengaruhi daya yang dihasilkan oleh PV. Hal ini dikarenakan listrik yang akan dijual kembali ke grid adalah berasal dari daya yang dihasilkan oleh PV. Dapat dilihat pada Energy Purchased menunjukan angka $158.788 \mathrm{kWh}$ sedangkan Energy Sold menunjukan angka $70.870 \mathrm{kWh}$.

Net Purchased adalah Kwh tetap yang dibeli (jikalau positif) atau dijual (jikalau negatif) . Net Purchased didapatkan melalui hasil pengurangan dari Energy Purchased dan Energy Sold. Dapat dilihat di gambar 10 pada kolom Net Purchased menunjukan angka 87.918 $\mathrm{kWh}$. 
Sedangkan Energy Charge adalah harga yang harus dibayarkan setiap bulannya. Angka ini diperoleh dengan cara Energy Purchased dikalikan dengan harga beli per kWh nya setelah itu dikurangi hasil dari Energy Sold dikalikan harga jual per kWh nya. Dapat dilihat di gambar 10 pada kolom Energy Charge menunjukan angka \$3.944

Tabel 4. Hasil Simulasi Grid Pada HOMER

\begin{tabular}{lcccccc}
\hline & $\begin{array}{c}\text { Energy } \\
\text { Purchased } \\
(\mathrm{kWh})\end{array}$ & $\begin{array}{c}\text { Energy } \\
\text { Sold } \\
(\mathrm{kWh})\end{array}$ & $\begin{array}{c}\text { Net } \\
\text { Purchases } \\
(\mathrm{kWh})\end{array}$ & $\begin{array}{c}\text { Peak } \\
\text { Demand } \\
(\mathrm{kW})\end{array}$ & $\begin{array}{c}\text { Energy } \\
\text { Charge }\end{array}$ & $\begin{array}{c}\text { Demand } \\
\text { Charge }\end{array}$ \\
\hline Jan & 16,040 & 4,428 & 11,611 & 114 & 556 & $(\$)$ \\
Feb & 12,365 & 5,120 & 7,244 & 109 & 330 & 0 \\
Mar & 12,369 & 6,439 & 5,931 & 104 & 254 & 0 \\
Apr & 13,404 & 5,291 & 8,113 & 110 & 373 & 0 \\
May & 13,883 & 5,884 & 7,998 & 114 & 363 & 0 \\
Jun & 11,105 & 7,352 & 3,753 & 104 & 137 & 0 \\
Jul & 11,584 & 6,834 & 4,751 & 100 & 191 & 0 \\
Aug & 12,451 & 6,263 & 6,188 & 100 & 268 & 0 \\
Sep & 10,207 & 7,730 & 2,477 & 105 & 70 & 0 \\
Oct & 14,429 & 5,397 & 9,032 & 116 & 419 & 0 \\
Nov & 15,999 & 4,674 & 11,325 & 123 & 540 & 0 \\
Dec & 14,952 & 5,457 & 9,495 & 117 & 442 & 0 \\
Annual & 158,788 & 70,870 & 87,918 & 123 & 3,944 & 0 \\
\hline
\end{tabular}

\subsection{Produksi Listrik Sebelum Bersistem Hibrida}

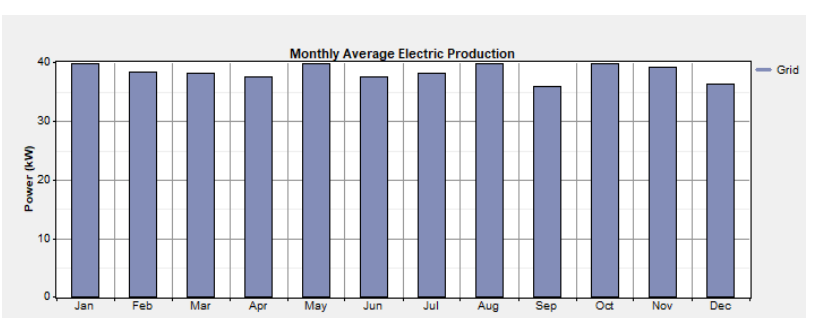

Gambar 11. Produksi energi listrik pada sistem Gird-Beban

Gambar 11 menunjukan bahwa total sumber daya listrik yang dihasilkan berasal dari Grid. Total Produksi listrik yang dihasilkan oleh sistem Grid pertahun sebesar 335.781 .

Tabel 5 adalah hasil simulasi dari HOMER, gambar di atas menunjukkan angka Energi yang dibeli ( Energy Purchased), Energi yang terjual (Energy Sold) , Net Purchases, Peak Demand, Energy Charge dan Demand Charge.

Dapat dilihat pada kolom energy sold bernilai 0 , hal ini dikarenakan tidak adanya energi listrik yang dapat dijual kembali ke grid, dikarenakan tidak adanya sumber energi lain selain grid yang menghasilkan energi listrik. Sedangkan pada kolom energy charge terlihat harga yang harus dibayarkan setiap bulannya dan total per tahunnya adalah \$17.015 hal ini sesuai dengan harga Operating Cost pada hasil optimasi grid-beban.
Tabel 5. Hasil simulasi Grid

\begin{tabular}{|c|c|c|c|c|c|c|}
\hline Month & $\begin{array}{c}\text { Energy } \\
\text { Purchase } \\
\text { d } \\
(\mathrm{kWh})\end{array}$ & $\begin{array}{c}\text { Energ } \\
y \\
\text { Sold } \\
(\mathrm{kWh})\end{array}$ & $\begin{array}{c}\text { Net } \\
\text { Purchase } \\
\text { s } \\
\text { (kWh) }\end{array}$ & $\begin{array}{c}\text { Peak } \\
\text { Deman } \\
d \\
(\mathrm{~kW})\end{array}$ & $\begin{array}{c}\text { Energ } \\
y \\
\text { Charg } \\
\text { e } \\
(\$) \\
\end{array}$ & $\begin{array}{c}\text { Deman } \\
\text { d } \\
\text { Charge } \\
(\$)\end{array}$ \\
\hline Jan & 29,546 & 0 & 29,546 & 128 & 1,497 & 0 \\
\hline Feb & 25,731 & 0 & 25,731 & 128 & 1,304 & 0 \\
\hline Mar & 28,312 & 0 & 28,312 & 128 & 1,435 & 0 \\
\hline Apr & 27,040 & 0 & 27,040 & 128 & 1,370 & 0 \\
\hline May & 29,546 & 0 & 29,546 & 128 & 1,497 & 0 \\
\hline Jun & 27,040 & 0 & 27,040 & 128 & 1,370 & 0 \\
\hline Jul & 28,312 & 0 & 28,312 & 128 & 1,435 & 0 \\
\hline Aug & 29,546 & 0 & 29,546 & 128 & 1,497 & 0 \\
\hline Sep & 25,806 & 0 & 25,806 & 128 & 1,308 & 0 \\
\hline Oct & 29,546 & 0 & 29,546 & 128 & 1,497 & 0 \\
\hline Nov & 28,275 & 0 & 28,275 & 128 & 1,433 & 0 \\
\hline Dec & 27,078 & 0 & 27,078 & 128 & 1,372 & 0 \\
\hline $\begin{array}{c}\text { Annu } \\
\text { al }\end{array}$ & 335,781 & 0 & 335,781 & 128 & $\begin{array}{c}17,01 \\
5\end{array}$ & 0 \\
\hline
\end{tabular}

\section{Kesimpulan}

Bedasarkan hasil simulasi HOMER dapat diliat daya yang harus disuplai oleh sistem PLTS ini untuk memenuhi kebutuhan beban adalah sebesar $920 \mathrm{kWh} /$ hari dengan beban puncak 128 , beban rata-rata $38,3 \mathrm{Kw}$, dan faktor beban 0,300 dan hasil optimasi pada homer menunjukan konfigurasi yang paling optimal yaitu PV-Grid-GeneratorInverter dan Grid-PV-Inverter. Karna memiliki nilai NPC yang paling rendah yaitu \$ 164.449.Sementara Modal awal yang harus dikeluarkan untuk mengawali perencanaan sistem PLTH ini sebesar \$ 109.285.Daya yang dihasilkan saat bersistem PV-Grid adalah $255.530 \mathrm{kWh} /$ tahun untuk PV dan $158.788 \mathrm{kWh} /$ tahun untuk Grid.Konsumsi daya pertahun saat bersistem PV-Grid adalah sekitar 406.659 $\mathrm{kWh} /$ tahun.

Energi daya yang dibeli setiap tahun nya adalah sebesar $158.788 \mathrm{kWh}$, sedangkan energi yang terjual sebesar $70.870 \mathrm{kWh}$. Dan energi yang harus dibayarkan sebesar $\$ 3.944$.

\section{Referensi}

[1]. Universitas Diponegoro, 2018. Lokasi Univeritas Diponegoro. https://www.undip.ac.id/language/id/lokasi (diakses pada 15 Juli 2018)

[2]. Data IntensitasPenyinaran dan Radiasi Matahari 20152017. Badan Meteorologi Klimatologi dan Geofisika (BMKG) Jawa Tengah ,Stasiun Klimatologi Semarang 2014.

[3]. T. Lambert, P. Gilman, dan P. Lilienthal, "Micropower system modeling with HOMER", Mistaya Engineering Inc, National Renewable Energy Laboratory, USA, 2012.

[4]. T. C. Wijaya, "Optimasi potensi energi terbarukan untuk sistem pembangkit hybrid di Desa Margajaya Bengkulu Utara menggunakan perangkat lunak HOMER", Skripsi, Teknik Elektro, Universitas Diponegoro, Semarang, 2014. 
[5]. Lambertus Sinaga, "Optimasi Sistem Pembangkit Listrik Hibrida Tenaga Surya, Angin, Biomassa, dan Diesel di Pulau Nyamuk Karimunjawa Jawa Tengah Dengan Menggunakan Perangkat Lunak HOMER" Skripsi, Teknik Elektro, Universitas Diponegoro, Semarang, 2015.

[6]. Agus, S, I Kadek, Analisa Unjuk Kerja Pembangkit Listrik Tenaga Surya (PLTS) 1 MWp Terinterkoneksi Jaringan Di Kayubihi, Bangli. Denpasar, Universitas Udayana, 2008.

[7]. Jurnal Taufik Wijaya "Optimasi potensi energi terbarukan untuk sistem pembangkit hybrid di Desa Margajaya Benngkulu Utara menggunakan perangkat lunak HOMER"
[8]. ABB, Technical Application Papers N0.10Photovoltaic Plants, Bergamo Italy, 2008,

[9]. Omran, Walid, Performance Analysis of Grid-Connected Photovoltaic Systems, Electrical and Computer Engineering University of Waterloo, 2010.

[10]. "Getting started guide for HOMER legacy version 2.68", National Renewable Energy Laboratory of USA, USA. 2011.

[11]. Spesifikasi Panel Surya YL320P-35b

[12]. Spesikasi Inverter Princeton Power System tipe GTIB $100 \mathrm{GI} 2$

[13]. Universitas Diponegoro, 2018. Lokasi Univeritas Diponegoro. https://www.undip.ac.id/language/id/lokasi (diakses pada 15 Juli 2018) 